\section{Gibberellin Levels Are Not a Suitable Indicator for Properly Cold-treated Tulip Bulbs}

\author{
Mariken Rebers ${ }^{1}$, Evert Vermeer, Erik Knegt, and \\ Linus H.W. van der Plas \\ Department of Plant Physiology, Wageningen Agricultural University, \\ Arboretumlaan 4, NL-6703BD Wageningen, The Netherlands
}

Additional index words. cold-induced growth, cold requirement, flowering assay, Tulipa gesneriana

\begin{abstract}
To find a suitable indicator for properly cold-treated tulip bulbs (Tulipa gesneriana L. cv. Apeldoorn), the content of the endogenous free gibberellins (GAs) $\mathbf{G A}_{1}$, $\mathbf{G A}_{4}, \mathbf{G A}_{9}, \mathbf{G A}_{24}$, and $\mathbf{G A}_{34}$ was investigated. GA levels were measured in the shoots and basal plates at the start and at the end of a complete cold treatment of 12 weeks at $5^{\circ} \mathrm{C} \mathrm{by}$ combined gas chromatography-mass spectrometry using deuterated internal standards. Bulbs stored at $17^{\circ} \mathrm{C}$ for 12 weeks served as controls and the experiment was repeated three times. Before the cold treatment, $\mathbf{G A}_{1}$ and $\mathbf{G A}_{4}$ were the major occurring $\mathrm{GAs}$ in the shoots. After 12 weeks, $\mathbf{G A}_{4}$ was the main $\mathrm{GA}$ component and the levels of $\mathbf{G A}_{1}$ were low in precooled and nonprecooled bulb shoots. The levels of $\mathbf{G A}_{4}, \mathbf{G A}_{9}, \mathbf{G A}_{24}$, and $\mathbf{G A}_{34}$ in precooled and nonprecooled bulb shoots and basal plates were similar. Hence, no direct correlation between cold-stimulated growth and a change in the endogenous GA status in shoots or basal plates was determined during the cold treatment. The free GA content in shoots or basal plates at the end of bulb storage cannot be used as a marker in a test for properly cold-treated 'Apeldoorn' tulip bulbs.
\end{abstract}

The flowering processes of the tulip can be divided into three temperature-dependent phases (Le Nard and De Hertogh, 1993). In the first phase, the flower is initiated at moderate temperatures $\left(17\right.$ to $\left.20^{\circ} \mathrm{C}\right)$. In the second phase, low temperatures $\left(2\right.$ to $\left.9^{\circ} \mathrm{C}\right)$ are required to prepare the shoot for the third phase, in which rapid floral stalk elongation and flower development occurs, again at 17 to $20^{\circ} \mathrm{C}$. The duration of the cold treatment is a major factor determining the development of floral stalk and flower after planting the bulb (Le Nard and De Hertogh, 1993). For 'Apeldoorn', 12 weeks precooling at $5^{\circ} \mathrm{C}$ before planting at 20 ${ }^{\circ} \mathrm{C}$ promotes optimal floral stalk elongation and flower development. Shorter periods at 5 ${ }^{\circ} \mathrm{C}$ usually produce slower shoot elongation, delayed flowering, and sometimes flower abortion (Le Nard and De Hertogh, 1993).

An assay to determine if a tulip cultivar has

Received for publication 24 Oct. 1995. Accepted for publication 26 Apr. 1996. This research was supported by the Bulb Research Centre, Lisse, The Netherlands. We acknowledge N. Murofushi, Univ. of Tokyo, Japan, for the gift of $\mathrm{GA}_{24}$ and C.J. Shelton and B. Twitchin at the Research School of Chemistry, Canberra, Australia, for the synthesis of $\mathrm{GA}_{3}$ and $\left[17,17-{ }^{2} \mathrm{H}_{2}\right] \mathrm{GA}_{34}$. The cost of publishing this paper was defrayed in part by the payment of page charges. Under postal regulations, this paper therefore must be hereby marked advertisement solely to indicate this fact.

${ }^{1}$ Current address: Frontier Research Program, Institute of Physical and Chemical Research (RIKEN), Wako-shi, Saitama 351-01, Japan. received a proper cold treatment would be desirable. Previous studies have been conducted on physiological changes occurring in carbohydrate and amino acid metabolism (Gorin et al., 1990; Gorin and Heidema, 1985; Heidema et al., 1985; Lambrechts et al., 1992; Lukaszewska et al., 1989; Tonecki and Gorin, 1990) and chalcone content (Franssen and Kersten, 1992). None of these has provided a satisfactory assay.

The involvement of gibberellins (GAs) has been implicated in the growth and development of cold-requiring plants, including the tulip. Application of GAs to tulip bulbs partly replaced the cold treatment (van Bragt and van Ast, 1976). In addition, studies using bioassay procedures reported an increase in the endogenous levels of GA-like substances during the cold treatment of tulip bulbs (Aung and De Hertogh, 1967). Thus, the measurement of the total amount of endogenous GAs, or the amount of an active GA, may be a suitable test for properly cold-treated bulbs, perhaps in combination with a rapid and reliable immuno-specific assay, such as enzyme-linked immunosorbent assay (ELISA). In previous studies, we demonstrated the presence of $\mathrm{GA}_{1}, \mathrm{GA}_{4}$, $\mathrm{GA}_{9}, \mathrm{GA}_{12}, \mathrm{GA}_{24}$, and $\mathrm{GA}_{34}$ in tulip shoots of 'Apeldoorn' by combined gas chromatography-mass spectrometry (Rebers et al., 1994, 1995). In the present study, we measured the endogenous levels of the free gibberellins $\mathrm{GA}_{1}$, $\mathrm{GA}_{4}, \mathrm{GA}_{9}, \mathrm{GA}_{24}$, and $\mathrm{GA}_{34}$ at the start and at the end of precooling $\left(12\right.$ weeks $\left.5{ }^{\circ} \mathrm{C}\right)$ or nonprecooling (control; 12 weeks $17{ }^{\circ} \mathrm{C}$ ) of bulbs using deuterated gibberellins as internal standards, to provide an indicator for the proper cold treatment of tulip bulbs.
Field-grown bulbs (cv. Apeldoorn) were harvested in July 1990, 1991, and 1992. They were stored in a dark, ventilated room at 20 ${ }^{\circ} \mathrm{C}$ until the treatments were started in October. After an initial sampling of 250 bulbs, they were transferred to dark ventilated rooms either at 5 or $17{ }^{\circ} \mathrm{C}$. After 12 weeks, shoots and basal plates (250 each) were isolated from the bulbs and stored at $-75^{\circ} \mathrm{C}$ until extraction.

GAs were extracted, purified, and analyzed as described previously (Rebers et al., 1995). Generally, quantification of GAs was performed in two to five independent analyses in which equal amounts of plant material were analyzed. The data were subjected to statistical analyses using a Student's $t$ test $(P$ $\leq 0.05)$.

\section{Results and Discussion}

During precooling and nonprecooling, the concentrations of $\mathrm{GA}_{1}$ and $\mathrm{GA}_{34}$ in shoots decreased to very low levels (Fig. 1, top). The decrease of the level of $\mathrm{GA}_{34}$ was significant in precooled and nonprecooled shoots (Student's $t$ test, $P \leq 0.05)$. For $\mathrm{GA}_{1}$, the concentration in precooled shoots was significantly lower than in nonprecooled shoots. It is unlikely, however, that a reliable ELISA can be developed based on the lower $\mathrm{GA}_{1}$ level in precooled shoots. $\mathrm{GA}_{1}$ occurs in very small quantities in tulip shoots, and due to cross reactivity, the levels of other GAs could interfere with the assay (Yamaguchi and Weiler, 1991). For $\mathrm{GA}_{4}, \mathrm{GA}_{9}, \mathrm{GA}_{24}$, and $\mathrm{GA}_{34}$, there were no significant differences between shoots from precooled and nonprecooled bulbs at the end of the storage period.

To correlate an increase or decrease in GA level during storage with the cold-stimulated growth and full flower development at subsequent higher temperatures, a change in GA level should be limited to either precooled or nonprecooled bulbs. We found that the levels of some GAs changed during storage, but no change was correlated to precooled or nonprecooled bulbs. Therefore, it is unlikely that the levels of free GAs in shoots at the end of bulb storage can be directly correlated with floral stalk elongation and full flower development after planting at 17 to $20^{\circ} \mathrm{C}$.

Basal plates (Aung et al., 1971) and bulb roots (Kawa-Miszczak et al., 1992) have been suggested as sites of GA biosynthesis. Thus, the basal plates comprising the root primordia also were analyzed (Fig. 1, bottom), but no significant changes occurred in the GA levels during storage. Therefore, the free GA concentration in basal plates at the end of bulb storage is not a satisfactory marker for properly cold-treated 'Apeldoorn' tulip bulbs.

In earlier studies, total levels of GA-like substances were measured using bioassay procedures. Van Bragt (1971), using 'Apeldoorn' and a dwarf pea (Pisum sativum L.) bioassay, reported almost equal levels of gibberellins in shoots per gram fresh mass after 12 weeks of bulb storage at either 5 or $20^{\circ} \mathrm{C}$. In the present 


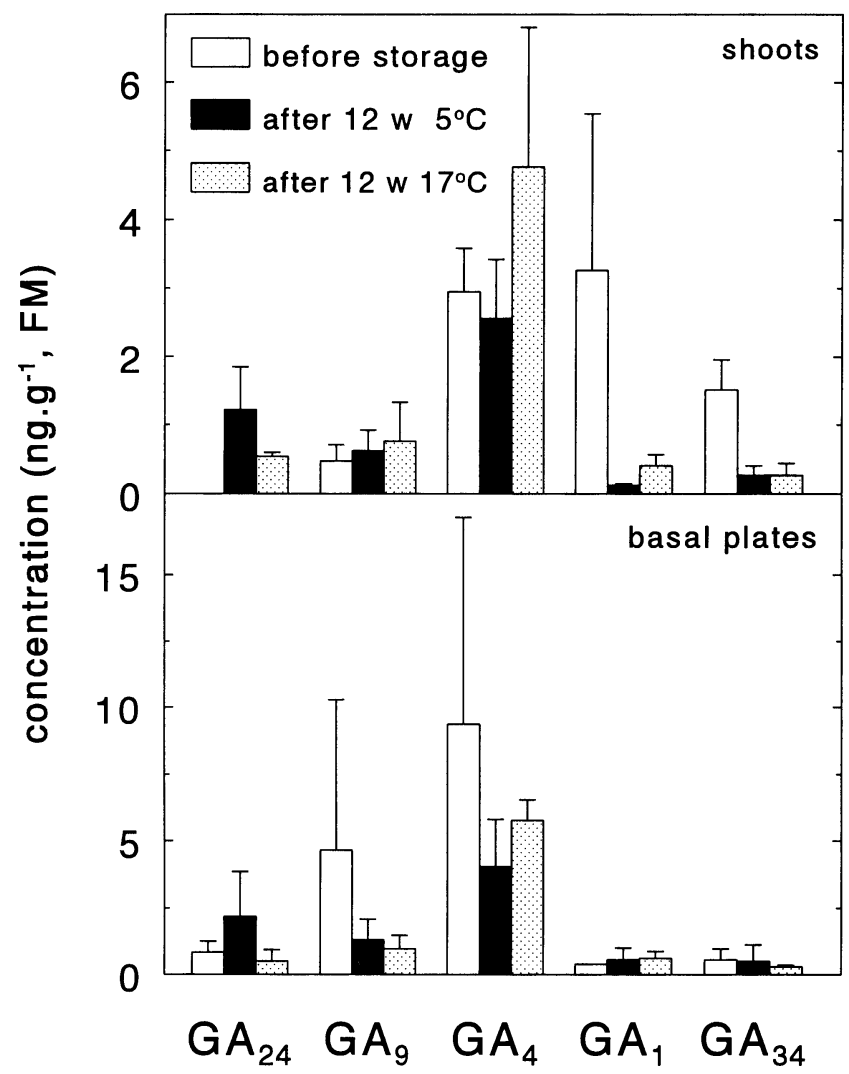

Fig. 1. Endogenous levels of (in metabolical order) $\mathrm{GA}_{24}, \mathrm{GA}_{9}, \mathrm{GA}_{4}, \mathrm{GA}_{1}$, and $\mathrm{GA}_{34}$ in shoots and basal plates before cold storage and after precooling $\left(12\right.$ weeks $\left.5^{\circ} \mathrm{C}\right)$ or no precooling $\left(12\right.$ weeks $\left.17^{\circ} \mathrm{C}\right)$. The results of three harvest years were averaged. Each bar represents the mean of three to six measurements, except for $\mathrm{GA}_{1}(\mathrm{n}=2-5)$. Error bars indicate standard deviations. The $\mathrm{GA}_{24}$ concentration in shoots at the beginning of bulb storage is not included in the figure, due to the large variation in results $[9.00 \pm 8.05$ $\mathrm{ng} \cdot \mathrm{g}^{-1}$ fresh mass (FM)].

study (Fig. 1, top), at the end of 5 or $17^{\circ} \mathrm{C}$ bulb treatment, shoots had almost identical total GA levels per gram fresh mass (5 and $7{\mathrm{ng} \cdot \mathrm{g}^{-1}}^{-1}$ fresh mass, respectively). These levels were basically the same as those of van Bragt (1971), expressed as nanogram $\mathrm{GA}_{3}$ equivalents per gram fresh mass. In conclusion, neither the concentration of a particular GA nor the total content of free GAs in bulb shoots at the end of bulb storage is a suitable criterion in a test for properly cold-treated bulbs.

\section{Literature Cited}

Aung, L.H. and A.A. De Hertogh. 1967. The occurrence of gibberellin-like substances in tulip bulbs (Tulipa sp.). Plant Cell Physiol. 8:201-205.

Aung, L.H., A.A. De Hertogh, and G.L. Staby. 1971. The alteration of bulb hormones content by environmental stimuli. Acta Hort. 2:156-161.

Franssen, J.M. and C.H. Kersten. 1992. Chalcones: A possible parameter to test the cold duration of tulip (Tulipa gesneriana cv. Apeldoorn) bulbs? Acta Hort. 325:259-266.

Gorin, N. and F.T. Heidema. 1985. Starch content of freeze-dried anthers and $\alpha$-amylase activity of their extracts as criteria that dry-stored bulbs (Tulipa gesneriana L.) cultivar 'Apeldoorn' have been exposed to $5{ }^{\circ} \mathrm{C}$. Sci. Hort. 26:183-189.

Gorin, N., J. Tonecki, and J.M. Franssen. 1990. Effect of starting date and temperature of storage on changes in free amino acids in anthers from bulbs of tulip cv. Apeldoorn, as related to the special precooling. Acta Hort. 266:155-162.

Heidema, F.T., G. Grevers, N. Gorin, C.T.C. van der Hulst, and J.M. Franssen. 1985. Criteria related to precooling of tulip bulbs cv. Apeldoorn at 5 ${ }^{\circ} \mathrm{C}$. Acta Hort. 177:341-346.

Kawa-Miszczak, L., E. Wegrzynowicz, and M. Saniewski. 1992. The effect of removal of roots and application of plant growth regulators on tulip shoot growth. Acta Hort. 325:71-76.

Lambrechts, H., J.M. Franssen, and C. Kollöffel. 1992. The 4-methylene-glutamine : asparagine ratio in the shoot of tulip bulbs cv. 'Apeldoorn' as a criterion for dry storage at $5{ }^{\circ} \mathrm{C}$. Sci. Hort. 52:105-112.

Le Nard, M. and A.A. De Hertogh. 1993. Tulipa, p. 617-682. In: A. De Hertogh and M. Le Nard (eds.). The physiology of flower bulbs. Elsevier, Amsterdam.

Lukaszewska, A.J., N. Gorin, and N. Haanappel. 1989. Changes in the contents of four free amino acids in anthers from tulip bulbs cv 'Apeldoorn', stored at 5 or $17{ }^{\circ} \mathrm{C}$, as criteria related to cold treatment. Sci. Hort. 38:269-275.

Rebers, M., E. Vermeer, E. Knegt, C.J. Shelton, and L.H.W. van der Plas. 1994. Gibberellins in tulip bulb sprouts during storage. Phytochemistry 36:269-272.

Rebers, M., E. Vermeer, E. Knegt, C.J. Shelton, and L.H.W. van der Plas. 1995. Gibberellin levels and cold-induced floral stalk elongation in tulip. Physiol. Plant. 94:687-691.

Tonecki, J. and N. Gorin. 1990. Further studies on the use of free amino acids in anthers from tulip bulbs cv. Apeldoorn as indicators about cold treatment at $5{ }^{\circ} \mathrm{C}$. Sci. Hort. 42:133-140.

Van Bragt, J. 1971. Endogenous gibberellin levels and floral stalk elongation in tulip cv. 'Apeldoorn'. Meded. Fak. Landbouwwet. Rijksuniv. Gent 36:1301-1307.

Van Bragt, J. and K.J. van Ast. 1976. Substition of the cold requirement of Tulip cv. 'Apeldoorn' by $\mathrm{GA}_{3}$. Sci. Hort. 4:117-122.

Yamaguchi, I. and E.W. Weiler. 1991. A minireview on the immunoassay for gibberellins, p. 146165. In: N. Takahashi, B.O. Phinney, and J. MacMillan (eds.). Gibberellins. Springer-Verlag, New York. 